\title{
Patiëntenvoorlichting
}

\section{PV 42. Latente botcyste}

Een latente botcyste is de benaming van een donkere plek op een röntgenfoto die in de hoek van de onderkaak kan worden aangetroffen. Het is een relatief zeldzame bevinding, die niet blijkt te berusten op een afwijking, maar eenvoudigweg wordt veroorzaakt door een onschuldige indeuking aan de binnenkant van de onderkaak. Er zijn dan ook geen klachten en het gaat altijd om een toevalsbevinding op een röntgenfoto die om een andere reden is gemaakt. Dit verschijnsel wordt alleen bij volwassenen aangetroffen, vooral bij mannen. Waarom dit verschijnsel vaker bij mannen dan bij vrouwen voorkomt, is onbekend.

In de meeste gevallen zijn de plaats en het aspect van de meestal ronde of ovaalvormige donkere plek voldoende kenmerkend om de diagnose te kunnen stellen. Bij twijfel wordt wel eens aanvullend onderzoek uitgevoerd, bij voorbeeld in de vorm van een CT- scan. Slechts een enkele maal is er, met name bij een afwijkende ligging, vorm of grootte behoefte aan inspectie van het kaakbot.

De indeuking leidt niet tot verzwakking van het kaakbot en leidt nooit tot een kaakbreuk. Het beeld van de röntgenfoto blijkt in de loop der jaren niet te wijzigen en er is geen reden om de afwijking regelmatig met behulp van röntgenfoto's te vervolgen.

\section{Wat kunt u zelf doen?}

Er zijn geen mogelijkheden, en er is vanwege het ontbreken van klachten ook geen enkele noodzaak, om (zelf) iets aan de indeuking van de onderkaak te doen. Er is geen gevaar van een kaakbreuk en er is geen controle vereist.

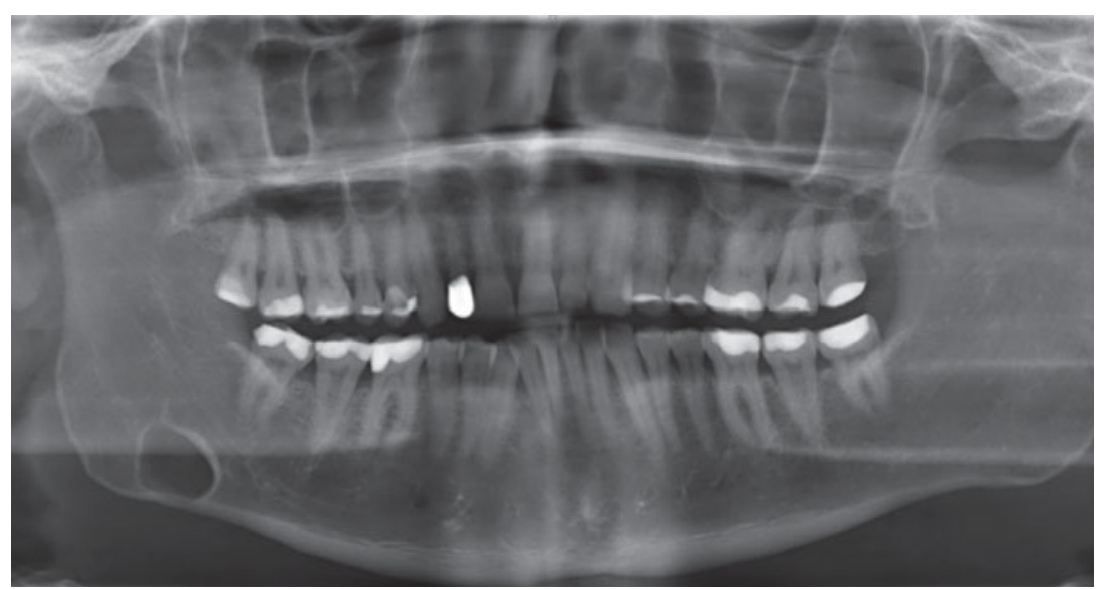

